\title{
Effect of ozone treatment on physicochemical parameters and ethylene biosynthesis inhibition in Guichang Kiwifruit
}

\author{
Sen $\mathrm{CAO}^{1,2 \dagger}\left(\mathbb{D}\right.$, Lingshuai MENG ${ }^{1,2 \dagger}$, Chao $\mathrm{MA}^{2}$, Liangjie $\mathrm{BA}^{1,2}$, Jiqing $\mathrm{LEI}^{1,2}$, Ning JI ${ }^{1,2}$, Rui $\mathrm{WANG}^{1,2^{*}}$
}

\begin{abstract}
To determine whether ozone can regulate fruit ripening and delay fruit aging, Kiwifruit (Actinidia deliciosa 'Guichang') was fumigated with different ozone concentrations $(100 \mu \mathrm{L} / \mathrm{L}, 200 \mu \mathrm{L} / \mathrm{L}, 300 \mu \mathrm{L} / \mathrm{L})$ for $3 \mathrm{~h}$, stored at $1{ }^{\circ} \mathrm{C}$ and $85 \pm 5 \% \mathrm{RH}$ for three months, and then matured at $20^{\circ} \mathrm{C}$ and $85 \%$ RH for 12 days. Compared with controls, the optimal concentration of ozone delayed kiwifruit ripening during cold storage by delaying the respiratory burst that precedes fruit decay. Consequently, fruit firmness, nutrient content, and enzyme activity remained stable; the expression of AdACS1 and AdACO1 as well as the activity of ACC synthetase (ACS) and ACC oxidase (ACO) was downregulated, whereby ACC and MACC were accumulated. In addition, ozone-treated fruit showed significantly reduced infection with grey mold. The effect of ozone on kiwifruit at $200 \mu \mathrm{L} / \mathrm{L}$ was the best suited for delaying fruit senescence, maintaining high quality during storage and fruit ripening compared with other fruits. Overall, our study indicated that ozone may play a major residual role in the physiological process of fruit ripening; furthermore, ozone can affect ethylene biosynthesis and fruit changes associated with endogenous ethylene production.
\end{abstract}

Keywords: ozone; kiwifruit; storage; ethylene biosynthesis; physicochemical parameters.

Practical Application: Qzone treatment was developed into a new method for kiwifruit storage and preservation.

\section{Introduction}

Besides having export potential, stems, leaves, flowers, roots, and fruits of horticultural plants contain a series of nutrients that are very important for human diet, including minerals, vitamins, and cellulose, among other important constituents (Han et al., 2017; Mlček et al., 2015; İpek et al., 2016). In general, postharvest storage and preservation technology are the continuation of fruit and vegetable production in the field, and an important guarantee for the sustainable development of the fruit and vegetable industry. However, owing to overripening, great losses of harvested fruits occur around the world annually. Further, ethylene can induce and accelerate fruit senescence, which causes the fruit industry to face enormous economic losses every year (Martínez-Romero et al., 2007).

Actinidia chinensis Planch, (Actinidiaceae), shows a variety of nutritional components and antioxidant functions; further, it contains healthcare factors that can prevent various diseases. Therefore, it has recently attracted increasing attention (Di Francesco et al., 2018; Soufleros et al., 2001). Specifically, kiwifruit is a typical climacteric species, whereby harvested fruits show rapid ripening and softening (Yin et al., 2010). Additionally, losses during post-harvest directly limit storage life of kiwifruit (Michailides \& Elmer, 2000). Furthermore, several studies have shown that Botrytis is the main pathogenic fungus responsible for postharvest decay of kiwifruit (Barboni et al., 2010; Elmer \& Michailides, 2007). In addition to causing direct decay losses, fruits infected by Botrytis will also increase ethylene production, thus accelerating fruit softening (Niklis et al., 1997). At present, storage methods for fruits and vegetables mainly include cold storage, ice-temperature storage, modified atmosphere storage, and ozone treatment (Daş et al., 2006; Antunes \& Sfakiotakis, 2002; Tzortzakis et al., 2007; Bardas et al., 2010). In fact, no single storage method can produce the ideal fruit storage conditions. Moreover, growing worldwide social concern about increasing pathogen resistance against antifungal agents and pesticide residues that threaten the environment are now considered limiting factors for chemical control of kiwifruit rot (Bardas et al., 2010).

Ozone is a product of oxygen degradation produced when oxygen is discharge under high pressure or is irradiated with ultraviolet radiation. Ozone is commercially available as a gas or dissolved in water (Mahapatra et al., 2005), as it is used for post-harvest handling of fresh fruits and vegetables (Karaca \& Velioglu, 2007). Ozone treatment does not leave any residue on the products. Moreover, it can remove mycotoxins, inhibit or kill microorganisms contaminating foods (Karaca \& Velioglu, 2007; Selma et al., 2008; Bastos et al., 2019), degrade poly aromatic hydrocarbon and clarify sugarcane juice (Silva et al., 2018; Bernardi et al., 2019). In the United States of America, ozone has been listed as a substance "generally recognized as safe (GRAS)," which can be in direct contact with and applied on food (Minas et al., 2010). According to Minas et al. (2014), ozone treatment of kiwifruits effectively inhibited expression of ACS1 and ACO1, while it reduced ACS and ACO enzyme 
activities, whereby ethylene biosynthesis was severely reduced, ultimately delaying fruit softening. Shimizu et al. (1982) reported that fumigation with an ozone concentration of $200 \mu \mathrm{L} / \mathrm{L}$ for $4 \mathrm{~h}$ achieved the same effect (Gabler et al., 2010). Further, Minas et al. (2010) reported that ozone also had significant inhibitory effects on Botrytis. Although there are numerous reports on the methods for application of ozone treatment of fruits and vegetables in postharvest, to date, there are no relevant reports on ozone treatment of kiwifruit during the process of storage and pre-cooling, while there are a few reports exploring different concentrations of ozone to treat kiwifruit. Therefore, using Guichang' kiwifruit as the model for study, here we aimed to determine the optimum concentration of ozone for fruit preservation, and to study the effect of ozone on postharvest physiology and storage quality of kiwifruit in order to provide a new method for kiwifruit storage and preservation. The main goals of this study were to: (1) analyze the physical and chemical parameters, and enzyme activities after treatment of 'Guichang' kiwifruit with different concentrations of ozone during storage and shelf life; (2) analyze several key biomolecules and the related gene expression in the ethylene biosynthesis pathway in the process of maturation of kiwifruit affected by ozone; and lastly (3) analyze the effects of ozone on microorganisms in Guichang kiwifruit during storage and shelf life.

\section{Materials and methods}

\subsection{Plant materials}

Mature kiwifruits (Actinidia deliciosa) 'Guichang' selected for uniform size were obtained from Guizhou Peng Sheng Tong agriculture Limited Company in Guiyang, Guizhou province, China. All blemished or diseased fruits were discarded.

\subsection{Treatments}

Four hundred and eighty kilograms of kiwifruit were harvested on October 6, 2018. All sample groups were placed in polyethylene fresh-keeping bags (thickness $20 \mu \mathrm{m}$ ). Each bag was packed with $5 \mathrm{~kg}$ of fruit; in all, 120 bags were packed. These bags were placed in cold storage directly according to the different treatments for precooling; when temperature at the center of the fruit reached $1{ }^{\circ} \mathrm{C}$, ozone treatment was initiated. Ozone gas was generated from a laboratory corona discharge ozone-generator at $220 \mathrm{~V}$ and $50 \mathrm{~Hz}$ (Model L-1000, Tianjin, China). Ozone treatment was carried out in a chamber $\left(1 \mathrm{~m}^{3}\right)$ with gaseous ozone at different concentrations $(100,200$, or $300 \mu \mathrm{L} / \mathrm{L}$ ) based on preliminary optimization studies (data not shown); zero ozone concentration was set as control treatment. The temperature and relative humidity of the cold storage room were $1 \pm 0.5{ }^{\circ} \mathrm{C}$ and $85 \% \pm 5 \%$, respectively. The time of ozone treatment was $3 \mathrm{~h}$. Immediately after the treatment, the fresh-keeping bags were tightly sealed and stored in cold storage. After 60 days, three bags were randomly sampled for the determination of each index. Determinations were conducted after 60 days and again 60 days later during cold storage. Then, fruits were placed at $25 \pm 2{ }^{\circ} \mathrm{C}$ and $85 \% \pm 5 \% \mathrm{RH}$, and indexes were determined every 4 days.

\subsection{Decay rate}

The percentage of rotten fruit was used to express rotten rate. The rate was determined in triplicate using the same bags each time.

\subsection{Physicochemical properties}

\section{Firmness}

Fruit firmness was determined using a TA.XTplus Texture Analyzer (Stable Micro Systems, UK) fitted with a $7.9 \mathrm{~mm}$ diameter Effegi $^{\text {tix }}$ probe. After removal of skin and flesh, the probe was inserted to a depth of approximately $10 \mathrm{~mm}$ at a rate of $1 \mathrm{~mm} / \mathrm{s}$. Data were expressed as $\mathrm{kg} / \mathrm{cm}^{2}$. This determination was done using 15 fruits at each sampling.

\section{Respiratory rate and ethylene production rate}

The respiration rate of kiwifruit was measured using a Head-space Gas Analyzer through the Still-setting method. When conducting the measurement, six fruits were weighed and placed in a sealed container for $3 \mathrm{~h}$ at $25 \pm 1{ }^{\circ} \mathrm{C}$ (room temperature); then, carbon dioxide concentration was measured. The calculation Formula 1 was the following:

$X=\frac{\mathrm{V} \times \mathrm{N} \times 1.894 \times 1000}{\mathrm{~m} \times \mathrm{t}}$

where, $\mathrm{X}$ is the respiration rate $\left(\mathrm{CO}_{2} \cdot \mathrm{kg}^{-1} \cdot \mathrm{h}^{-1}\right) ; \mathrm{m}$ is the mass of the sample in $(\mathrm{kg}) ; \mathrm{V}$ is the container volume (l); $\mathrm{t}$ is the standing time (h); $\mathrm{N}$ is the volume fraction of $\mathrm{CO}_{2}(\%)$; and the value $1.894 \mathrm{~g} / \mathrm{L}$ is the density of carbon dioxide under normal pressure.

Ethylene production rate of kiwifruit was measured by gas chromatography using a programmed temperature rising method (GC-14 gas chromatography equipment, Japan). Chromatography conditions were as follows: column: Agilent, DB-5 (30 m× $0.25 \mathrm{~mm} \times 0.25 \mu \mathrm{m}$ ); Detector: FID; column temperature $230^{\circ} \mathrm{C}$; injection port temperature: $120^{\circ} \mathrm{C}$; heating program: $80^{\circ} \mathrm{C}$ for $2 \mathrm{~min}$ then temperature raised to $230^{\circ} \mathrm{C}$ at $6^{\circ} \mathrm{C} / \mathrm{min}$ and temperature was kept at $230^{\circ} \mathrm{C}$ for $1 \mathrm{~min}$. Carrier gas: $\mathrm{N}_{2}$; flow rate: $24 \mathrm{~mL} / \mathrm{min}$; Tail-blowing gas: $\mathrm{N}_{2}$, flow rate $30 \mathrm{~mL} / \mathrm{min}$, tail-blowing: $30 \mathrm{~mL} / \mathrm{min}$. Finally, six fruits were placed in a dryer at a time, and $10 \mathrm{~mL}$ of the gaseous phase was drawn for ethylene measurement after $3 \mathrm{~h}$.

\section{Total soluble solids (\%)}

Total soluble solids (TSS, \%) was determined by a hand-held sugar measuring instrument (Atago PAL-1, Japan). Analysis of TSS was repeated three times using six fruits each time.

\section{Titratable acidity (\%)}

Titratable acidity (TA, \%) was determined with an $\mathrm{NaOH}$ automatic $\mathrm{pH}$ titrator (916Ti-Touch potentiometric titrator, Switzerland) using citric acid as reference. Analysis of TA was repeated three times using six fruits each time. 


\section{Vitamin $C$ content}

Vitamin C (Vc) content was determined by molybdenum blue spectrophotometry. Briefly, $10.0 \mathrm{~g}$ of kiwifruit homogenate was weighed and placed in a volumetric flask; then, oxalic acidEDTA solution was added to a final volume of $100 \mathrm{~mL}$; after filtering, $10 \mathrm{~mL}$ of this homogenate solution was placed in a $50 \mathrm{~mL}$ volumetric flask, and added with $1.0 \mathrm{~mL}$ of metaphosphoric acid-acetic acid and $2.00 \mathrm{~mL}$ of $5 \%$ sulfuric acid. After gently shaking, $4.0 \mathrm{~mL}$ of ammonium molybdate solution was added and volume was brought to $50 \mathrm{~mL}$ with distilled water. Distilled water was used as a blank control and absorbance at $705 \mathrm{~nm}$ was measured to calculate Vc content.

\section{Superoxide dismutase activity}

Superoxide dismutase activity (SOD) was determined by pyrogallol colorimetry. Pyrogallol autoxidation rate test-blank was used as reference The reaction mixture contained $2.35 \mathrm{~mL}$ of $0.1 \mathrm{M}$ Tris $\mathrm{HCl}$ solution ( $\mathrm{pH}=8.20$ including $2.0 \mathrm{mM}$ EDTA), $2.15-\mathrm{V} 1-\mathrm{v} 0 \mathrm{~mL}$ of distilled water, $\mathrm{V} 1 \mathrm{~mL}$ of water bath sample solution, v0 $\mathrm{mL}$ of $4.5 \mathrm{~mol} / \mathrm{l}$ pyrogallol solution. The reaction mixture was vortexed for $3 \mathrm{~s}$ in a plastic centrifuge tube at $25^{\circ} \mathrm{C}$. Immediately following vortex treatment, the mixture was poured into the cuvette, covered, and placed in the sample slot of the UV spectrophotometer for immediate reading of absorbance at $325 \mathrm{~nm}$ at $30 \mathrm{~s}$ intervals during $4 \mathrm{~min}$. One enzyme activity unit (U) was defined as the amount of enzyme necessary to inhibit the autoxidation rate of pyrogallol by $35 \% \sim 65 \% \mathrm{~min}^{-1} \mathrm{~mL}^{-1}$ of reaction solution at constant temperature $\left(25^{\circ} \mathrm{C}\right)$.

\subsection{Polyphenol oxidase activity and polygalacturonase activity}

Polyphenol oxidase (POD) activity was assayed by the guaiacol method, with slight modifications according to Chen \& Wang (1989). Briefly we weighed $3 \mathrm{~g}$ of flesh tissue (samples were grinded in liquid nitrogen in a refrigerator at $-78^{\circ} \mathrm{C}$ ), and added $15 \mathrm{~mL}$ of $50 \mathrm{mM}$ sodium phosphate buffer ( $\mathrm{pH} 5.5$ ), then samples were grinded in an ice bath, and centrifuged at $10000 \times g$ at $4{ }^{\circ} \mathrm{C}$ for $15 \mathrm{~min}$. The supernatant was used for POD activity assay by mixing $3.0 \mathrm{~mL}$ of $25 \mathrm{mM}$ guaiacol solution with $0.5 \mathrm{~mL}$ of enzyme extract in a test tube. Then, $0.5 \mathrm{~mL}$ of $\mathrm{H}_{2} \mathrm{O}_{2}$ solution with mass fraction of $1 \%$ were added and mixed to start the reaction. The reaction mixture was then poured into a cuvette and absorbance at $460 \mathrm{~nm}$ was measured for $15 \mathrm{~s}$, and then recorded at $30 \mathrm{~s}$ intervals with continuous measuring so as to obtain data of at least 6 time points. The assay was conducted in triplicate using distilled water as reference.

As for polygalacturonase activity (PG), $0.4 \mathrm{~mL}$ of supernatant was added with $3.8 \mathrm{~mL}$ of $0.5 \%$ pectin solution $(\mathrm{pH} 4.0)$ and $2.5 \mathrm{~mL} \mathrm{DNS}$; after $30 \mathrm{~min}$ of reaction at $37^{\circ} \mathrm{C}$, the reaction was stopped by boiling for $5 \mathrm{~min}$, then cooled in a water bath to room temperature; the buffer solution was then fixed to $25 \mathrm{~mL}$. Each sample was determined in duplicate. Samples were kept at $4{ }^{\circ} \mathrm{C}$ in a refrigerator, At the time of measurement, $10 \mathrm{~mL}$ of each sample was poured into a $10 \mathrm{~mL}$ centrifuge tube and centrifuged again at $10000 \times g$ and $4{ }^{\circ} \mathrm{C}$ for $5 \mathrm{~min}$; after centrifugation, the supernatants were transferred to the EP tubes after pre-freezing treatment immediately following centrifugation. According to the difference between the absorbance values of the sample reaction tube and the control solution, the amount of the corresponding polygalacturonic acid was obtained from a standard curve. PG activity was expressed by the amount of polygalacturonic acid $\left(\mu \mathrm{g} \mathrm{g}^{-1} \mathrm{~min}^{-1}\right)$ hydrolyzed to galacturonic acid at $37^{\circ} \mathrm{C}$.

\subsection{Determination of ACC and 1-malonyl-ACC (MACC) content}

Ethylene precursor ACC and end metabolite MACC were quantified according to Bulens et al. (2011). Briefly, $5 \mathrm{~g}$ of

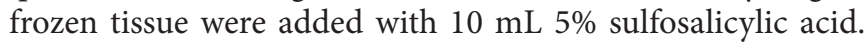
The homogeneous mixture was bathed at $4{ }^{\circ} \mathrm{C}$ for $30 \mathrm{~min}$, and centrifuged at $10000 \times g\left(4^{\circ} \mathrm{C}\right)$ for $10 \mathrm{~min}$; the supernatants were stored at $-78{ }^{\circ} \mathrm{C}$. Acid hydrolysis was carried out by adding $0.2 \mathrm{~mL}$ of $6 \mathrm{M}$ HCL to a microcentrifuge tube containing $0.5 \mathrm{~mL}$ ACC extract to release MACC and estimate the content of ACC + MACC; The acid was added in a $99^{\circ} \mathrm{C}$ water bath for $3 \mathrm{~h}$. After boiling, the sample was cooled and neutralized with $0.2 \mathrm{~mL} 6 \mathrm{M} \mathrm{NaOH}$, and centrifuged at $10000 \times g$ for $10 \mathrm{~min}$; the supernatants were collected and stored at $-18^{\circ} \mathrm{C}$. Each sample was subjected to two reactions to convert ACC to ethylene i.e., with or without $20 \mathrm{~mL}$ of $50 \mathrm{mM}$ ACC solution to calculate reaction efficiency. Using $1.4 \mathrm{~mL}$ of ACC extract and $0.4 \mathrm{~mL}$ of $10 \mathrm{mM} \mathrm{HgCl}_{2}$ placed in a $12 \mathrm{~mL}$ vial immediately sealed with a lid provided with a diaphragm, $0.2 \mathrm{~mL}$ of $6 \mathrm{M} \mathrm{NaOH}-5 \%$ (v/V) $\mathrm{NaOCl}(1: 2 \mathrm{~V} / \mathrm{V})$ was injected through the cap diaphragm with a syringe. The reaction mixture was incubated on melted ice for $4 \mathrm{~min}$ and then $1 \mathrm{~mL}$ sample was drawn from the headspace gas in the vial through the diaphragm and injected into the gas chromatograph for ethylene determination as described previously. In the determination of ACC + MACC, $0.1 \mathrm{~mL}$ hydrolytic ACC extract was added with $0.6 \mathrm{~mL}$ distilled water, $0.2 \mathrm{~mL}$ of $10 \mathrm{mM} \mathrm{HgCl}_{2}, 0.1 \mathrm{~mL} 6 \mathrm{M} \mathrm{NaOH}-5 \%$ v/V NaOCl $(1: 2 \mathrm{~V} / \mathrm{V})$. Free ACC content was determined from ACC extract, and MACC was expressed as nmol $\mathrm{g}^{-1}$ by subtracting the content of free ACC from total hydrolytic ACC.

\subsection{ACS and ACO enzyme activity}

The enzyme activity assay of both ACS and ACO were performed following the protocol of Bulens et al. (2011) with slight modifications. Briefly, for determination of ACS activity, $3.0 \mathrm{~g}$ of fruit flesh tissue were weighed, added with $10 \mathrm{~mL}$ of buffer A $(0.4 \mathrm{M}$ phosphate buffer, $\mathrm{pH} 8.5$, containing $1 \mathrm{mM}$ EDTA and $0.5 \% \beta$-mercaptoethanol and $10 \mu \mathrm{M}$ pyridoxal phosphate) and grinded into a uniform slurry, which was then centrifuged at $12000 \times \mathrm{g}$ for $30 \mathrm{~min}$ at $4{ }^{\circ} \mathrm{C}$. The supernatant was discarded and $1 \mathrm{~mL}$ of buffer $\mathrm{B}(0.4 \mathrm{M}$ phosphate buffer, pH 8.5, containing $1 \mathrm{mM}$ EDTA and $1 \mathrm{mM} \beta$-mercaptoethanol and $10 \mu \mathrm{M}$ pyridoxal phosphate as well as $0.1 \%$ Trixtonx-100) was added to the pellet and resuspended for precipitation. The preparation was left to stand for $30 \mathrm{~min}$ at $4{ }^{\circ} \mathrm{C}$ with frequent shaking for full extraction; then, it was centrifuged at $12000 \times g$ for $10 \mathrm{~min}$ at $4{ }^{\circ} \mathrm{C}$. The supernatant was used for enzyme activity assay as follows: $0.2 \mathrm{~mL}$ of enzyme solution was added to $0.8 \mathrm{~mL}$ of reaction buffer $(50 \mu \mathrm{M}$ SAM, $10 \mu \mathrm{M}$ pyridoxal phosphate, $50 \mathrm{mM}$ Hepes-KOH, pH 8. 5), after sealing with rubber stopper, 
the preparation was placed in a water bath for $1 \mathrm{~h}$ at $32{ }^{\circ} \mathrm{C}$,

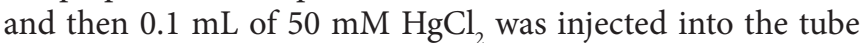
to terminate the reaction. After $5 \mathrm{~min}$ in an ice bath, $67 \mu \mathrm{L}$ of $5 \% \mathrm{NaClO}$ and $33 \mu \mathrm{L}$ of saturated $\mathrm{NaOH}$ was rapidly added to the reaction mixture. After shaking for $10 \mathrm{~s}$ and standing for $2 \mathrm{~min}$, extract $1 \mathrm{~mL}$ of gas from the headspace in the bottle was extracted with a syringe to determine ethylene concentration by gas chromatography as before. Each sample was analyzed in triplicate.

The assay of ACO enzyme activity was as follows: $0.5 \mathrm{~g}$ of sample powder was added with $1 \mathrm{~mL}$ of extraction solution consisting in $100 \mathrm{mM}$ Tris- $\mathrm{HCl}, 30 \mathrm{mM}$ sodium ascorbate $5 \%$ PVP, $0.1 \mathrm{mM} \mathrm{FeSO}_{4}, 5 \mathrm{mM}$ DTT, and 10\% glycerol, at pH 7.5, to a $1.5 \mathrm{~mL}$ centrifuge tube with gentle shaking to mix them evenly; the tubes were centrifuged at $12,000 \times g$ for $10 \mathrm{~min}$ at $4{ }^{\circ} \mathrm{C}$; then, $0.2 \mathrm{~mL}$ of the supernatant was sampled and injected into a sealed bottle containing $1.8 \mathrm{~mL}$ of reaction buffer consisting of $100 \mathrm{mM}$ Tris- $\mathrm{HCl}, 30 \mathrm{mM}$ sodium ascorbate $5 \%$ PVP, $0.1 \mathrm{mM} \mathrm{FeSO}_{4}, 30 \mathrm{mM} \mathrm{NaHCO}_{3}, 1 \mathrm{mM}$ ACC, 10\% glycerol, $\mathrm{pH} 7.5$, and incubated in a water bath at $30{ }^{\circ} \mathrm{C}$ for $20 \mathrm{~min}$, and then $1 \mathrm{~mL}$ of the headspace gas in the bottle was extracted to measure ethylene concentration by gas chromatography as before. Each sample was determined in triplicate.

\subsection{RNA isolation, cDNA synthesis and real time quantitative RT-PCR analysis of ethylene biosynthesis genes}

Extraction of RNA from kiwifruit samples was performed using the RNA extraction kit of Trizol Reagent (NO. B610409) of Sangon Biotech (Shanghai) Co., Ltd.; then, RNA was reverse transcribed into cDNA with One Step RT-qPCR Kit (NO. B639277). Then, fluorescence quantitative PCR was conducted as in Minas et al. (2014). Additionally, kiwifruit ACS1 and ACO1 gene sequences and fluorescent quantitative primers can be referred to Minas et al. (2014). Specific primers are shown in Supplementary Table 1.

\subsection{Evaluation of Botrytis}

The evaluation of Botrytis cinerea was determined in kiwifruit juice using an enzymatic dosage kit (control of the laccase activity). Results were compared with a reference index graded from 0 to 10 .

\subsection{Statistical analysis}

OriginPro 9.0 software was used to process the data statistically, while Duncan's new multiple range test was conducted to analyze differences in data using SPSS 190.0. Significance was set at $\mathrm{P}<0.05$.

\section{Results and discussion}

\subsection{Decay rate}

Color and flavor are important parameters of food commodity value (Schuch et al., 2018; Nascimento et al., 2020), and the decay rate of fruit affects its color and flavor, so it is also an important index of fruit storage period. Ozone treatment reduced decay rate of kiwifruit, particularly at $200 \mu \mathrm{L} / \mathrm{L}$, which had a significant effect on reduction of decay rate of kiwifruit (Figure 1). Moreover, the optimal duration for controlling post-harvest diseases in kiwifruit was determined at $30 \mathrm{~min}$ on the basis of preliminary screening tests. There was no significant difference between treatment and control groups within 60 days of cold storage $(\mathrm{P}>0.05)$, but at 120 days of cold storage, decay rate of the control group began to rise rapidly, while decay rate of the treatment group was significantly lower $(\mathrm{P}<0.05)$. As Figure 1 shows, decay rate of kiwifruit treated with ozone at $200 \mu \mathrm{L} / \mathrm{L}$ was significantly reduced. Palou, Crisosto, and Smilanick found that a low concentration of ozone had no inhibitory effect on Botrytis (Palou et al., 2002). In turn, Whangchai et al. (2006) found that ozone effectively oxidized the cellular components of microorganisms. Further, our results on decay rate showed that a low concentration of ozone was not effective for kiwifruit preservation, while the rapid increase of fruit decay at high ozone concentration during storage was likely due to ozonemediated oxidation of cell membranes in fruit flesh, thereby accelerating fruit decay.

\subsection{Physicochemical properties}

\section{Firmness}

The firmness of kiwifruit in the control group continued to decrease during storage, but the firmness of kiwifruit after ozone treatment decreased slowly after 6 days (Figure 2). Stec, Hodgson, and Macrae reported that when the firmness of Kiwifruit was $0.5-1.5 \mathrm{~kg} / 0.5 \mathrm{~cm}^{2}$, the fruit had a pleasant taste. After 4 days on the shelf following cold storage and ozone treatment, the firmness of the control group reached $1.46 \mathrm{~kg} / 0.5 \mathrm{~cm}^{2}$, which indicated that the kiwifruit was at the edible stage at this time (Stec et al., 1989). In contrast, the firmness of the treatment group was significantly higher than that of control group $(\mathrm{P}<0.05)$, which indicated that ozone treatment inhibited the decrease in firmness. Similarly, after 12 days on the shelf out of cold storage, the firmness of the kiwifruit treated with ozone at $200 \mu \mathrm{L} / \mathrm{L}$ reached $1.17 \mathrm{~kg} / \mathrm{cm}^{2}$ and was significantly higher

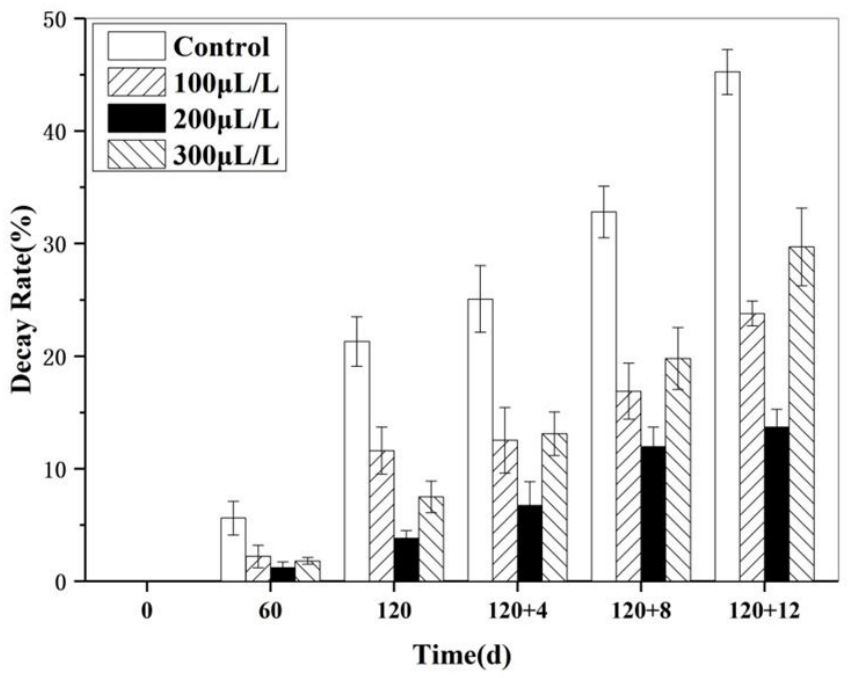

Figure 1. Effect of ozone $(0,100,200$, and $300 \mu \mathrm{L} / \mathrm{L})$ treatment on decay rate of kiwifruit during postharvest storage at $1 \pm 0.5^{\circ} \mathrm{C}$ and $85 \% \pm 5 \% \mathrm{RH}$. 
than that of the control group $(\mathrm{P}<0.05)$. However, there was no significant difference relative to the other two ozone treatment groups $(\mathrm{P}>0.05)$.

\section{Respiratory rate and ethylene production rate}

Usually, respiration rate is a significant indicator of storage effects. Under normal circumstances, the higher the respiration rate, the faster the consumption of stored nutrients (Navarro et al., 2006). On the contrary, ozone reduces fruit post-harvest decay and oxidizes ethylene in the fruit micro environment, thus extending the time of post-harvest refrigeration (Ong et al., 2013). After 120 days of cold storage, the control treatment, 100, and $300 \mu \mathrm{L} / \mathrm{L}$ treatments all reached a respiratory peak significantly $(\mathrm{P}<0.05)$ higher than the corresponding to $200 \mu \mathrm{L} / \mathrm{L}$ ozone treatment (Figure 3A). At the end of shelf life, respiration rate of fruits under the control treatment was significantly higher than that under ozone treatment $(\mathrm{P}<0.05)$, which indicated that ozone treatment significantly reduced the respiratory

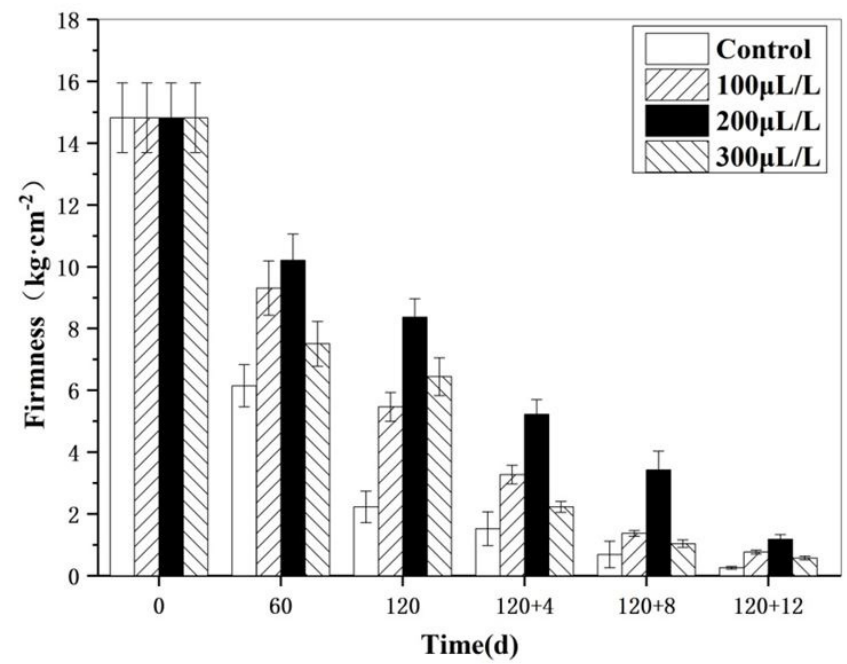

Figure 2. Effect of ozone $(0,100,200$, and $300 \mu \mathrm{L} / \mathrm{L})$ treatment on firmness of kiwifruit during postharvest storage at $1 \pm 0.5^{\circ} \mathrm{C}$ and $85 \%$ $\pm 5 \% \mathrm{RH}$. intensity and $200 \mu \mathrm{L} / \mathrm{L}$ ozone treatment was the most effective in reducing fruit respiratory rate. After 120 days of cold storage, fruits maintained a low ethylene production rate (Figure 3B), and there was no significant difference between ozone treatments $(\mathrm{P}>0.05)$. After 8 days on the shelf out of cold storage, ethylene production rate of different treatment groups reached a peak. At the end of shelf life, ethylene production rate of fruits treated with ozone at $200 \mu \mathrm{L} / \mathrm{L}$ was significantly lower than that of any other treatment group $(\mathrm{P}<0.05)$, which indicated that suitable ozone concentration was not only conducive to maintaining low respiratory rhythm and ethylene production rate, but it also slowed fruit physiological activities during storage. This finding was consistent with results reported by Minas et al. (2010).

Total soluble solids, titratable acidity, vitamin $C$, and superoxide dismutase activity

Sour and sweet play very important roles in different sensory characteristics evaluation methods of food (Costa et al., 2020). Generally, soluble solids content in different treatments first increased and then decreased (Table 1). We found no significant difference among ozone treatments $(\mathrm{P}>0.05)$ within 120 days of cold storage. Starting at 8 days on the shelf out of cold storage, soluble solids slightly decreased. However, at the end of shelf life period ( $12 \mathrm{~d}$ ), soluble solid content of ozone treated fruit was higher than that of the control fruit. This finding was consistent with results by Leccese et al. (2012). Thus, soluble solids content of kiwifruit treated with ozone at concentrations of 100 and $200 \mu \mathrm{L} / \mathrm{L}$ was significantly higher than in the control treatment $(\mathrm{P}<0.05)$, whereas no significant difference between ozone at $300 \mu \mathrm{L} / \mathrm{L}$ and the control treatment was detected $(\mathrm{P}>0.05)$. Titrable acid (TA) represents the content of organic acids in fruits and is a significant indicator of fruit maturity and taste (Melgarejo et al., 2000). During the period of cold storage and shelf life, TA of kiwifruit under the different treatments evaluated all showed a downward trend (Table 1). Further, ozone treatment reduced the loss of titratable acid content, which may be due to metabolic activity and fruit respiration rate. At the end of shelf life (12 d), TA content of kiwifruit treated with ozone at $200 \mu \mathrm{L} / \mathrm{L}$ was significantly higher than that of any other treatment $(\mathrm{P}<0.05)$.
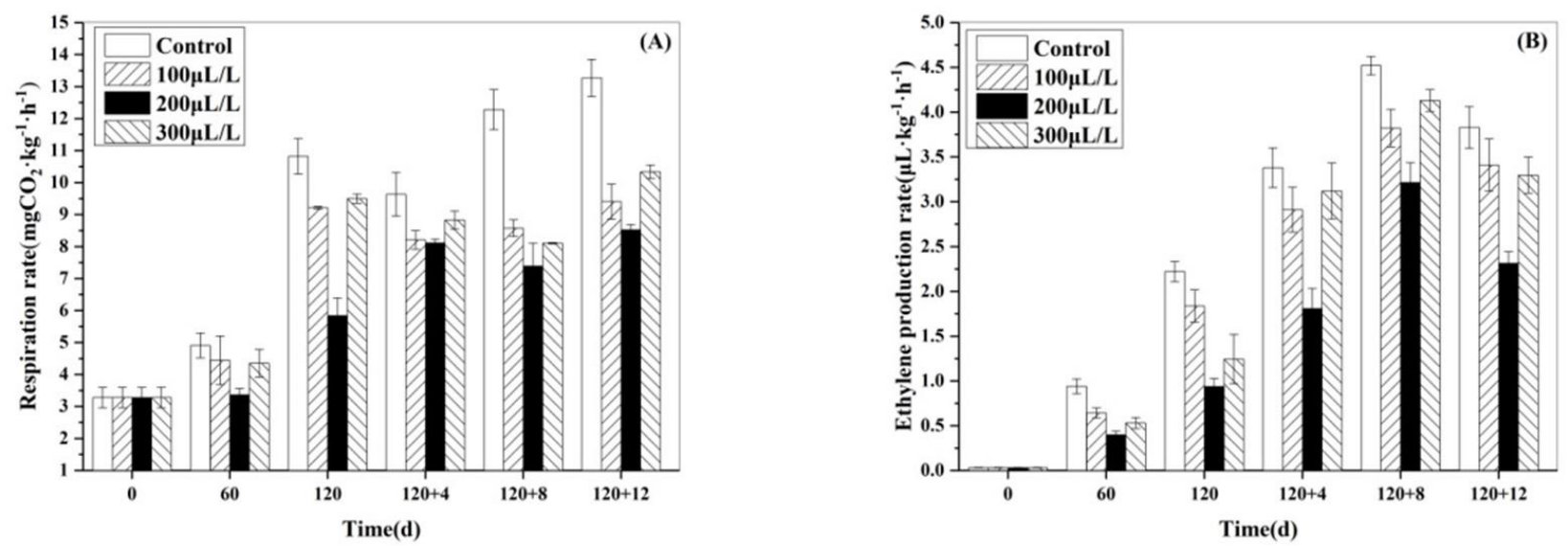

Figure 3. Effect of ozone $(0,100,200$, and $300 \mu \mathrm{L} / \mathrm{L})$ treatment on respiratory rate $(\mathrm{A})$ and ethylene production rate (B) in kiwifruit during postharvest storage at $1 \pm 0.5^{\circ} \mathrm{C}$ and $85 \% \pm 5 \% \mathrm{RH}$. 
Table 1. Effect of $\mathrm{O}_{3}$ treatments on TSS, TA, Vc, and SOD activity in kiwifruit fruits at post-harvest.

\begin{tabular}{|c|c|c|c|c|c|}
\hline \multirow{2}{*}{ Physicochemical properties } & \multirow{2}{*}{ Time $(\mathrm{d})$} & \multicolumn{4}{|c|}{ Treatment $(\mu \lambda / 1)$} \\
\hline & & 0 & 100 & 200 & 300 \\
\hline \multirow{6}{*}{ Total soluble solids (\%) } & 0 & $6.57^{\mathrm{a}}$ & $6.57^{\mathrm{a}}$ & $6.57^{\mathrm{a}}$ & $6.57^{\circ}$ \\
\hline & 60 & $8.78^{\mathrm{a}}$ & $8.30^{\mathrm{a}}$ & $8.15^{\mathrm{a}}$ & $8.98^{\circ}$ \\
\hline & 120 & $14.51^{\mathrm{a}}$ & $14.01^{\mathrm{a}}$ & $14.43^{\mathrm{a}}$ & $13.97^{\circ}$ \\
\hline & $120+4$ & $14.83^{\mathrm{b}}$ & $15.28^{\mathrm{ab}}$ & $15.68^{\mathrm{a}}$ & $14.86^{\mathrm{b}}$ \\
\hline & $120+8$ & $15.18^{c}$ & $16.12^{\mathrm{b}}$ & $17.58^{\mathrm{a}}$ & 15.22 \\
\hline & $120+12$ & $14.10^{c}$ & $15.26^{\mathrm{b}}$ & $17.21^{\mathrm{a}}$ & 14.20 \\
\hline \multirow{6}{*}{ Titratable acidity (\%) } & 0 & $1.68^{\mathrm{a}}$ & $1.68^{\mathrm{a}}$ & $1.68^{\mathrm{a}}$ & $1.68^{\circ}$ \\
\hline & 60 & $1.36^{\mathrm{c}}$ & $1.43^{\mathrm{bc}}$ & $1.57^{\mathrm{a}}$ & $1.45^{\mathrm{b}}$ \\
\hline & 120 & $1.17^{\mathrm{c}}$ & $1.28^{\mathrm{b}}$ & $1.40^{\mathrm{a}}$ & $1.24^{\mathrm{bc}}$ \\
\hline & $120+4$ & $0.93^{\mathrm{c}}$ & $1.21^{\mathrm{b}}$ & $1.36^{\mathrm{a}}$ & $1.23^{\mathrm{t}}$ \\
\hline & $120+8$ & $0.88^{c}$ & $1.04^{\mathrm{b}}$ & $1.28^{\mathrm{a}}$ & $1.08^{\mathrm{b}}$ \\
\hline & $120+12$ & $0.82^{\mathrm{b}}$ & $0.93^{\mathrm{b}}$ & $1.21^{\mathrm{a}}$ & $0.95^{\mathrm{b}}$ \\
\hline \multirow{6}{*}{ Vitamin C (mg/100 g) } & 0 & $116.90^{\mathrm{a}}$ & $116.90^{\mathrm{a}}$ & $116.90^{\mathrm{a}}$ & $116.90^{2}$ \\
\hline & 60 & $119.11^{\mathrm{a}}$ & $118.48^{\mathrm{a}}$ & $116.07^{\mathrm{a}}$ & $117.46^{\circ}$ \\
\hline & 120 & $119.71^{\mathrm{a}}$ & $119.55^{\mathrm{a}}$ & $120.19^{\mathrm{a}}$ & $119.19^{\circ}$ \\
\hline & $120+4$ & $120.37^{\mathrm{b}}$ & $119.62^{\mathrm{b}}$ & $126.48^{\mathrm{a}}$ & $123.37^{\mathrm{at}}$ \\
\hline & $120+8$ & $112.96^{\mathrm{b}}$ & $113.33^{\mathrm{b}}$ & $121.70^{\mathrm{a}}$ & $121.29^{\circ}$ \\
\hline & $120+12$ & $102.83^{\mathrm{d}}$ & $110.99^{\mathrm{b}}$ & $116.86^{\mathrm{a}}$ & 106.48 \\
\hline \multirow{6}{*}{$\begin{array}{l}\text { Superoxide dismutase activity } \\
\text { (U/g enzyme) }\end{array}$} & 0 & $332.59^{\mathrm{a}}$ & $332.59^{\mathrm{a}}$ & $332.59^{\mathrm{a}}$ & $332.59^{\circ}$ \\
\hline & 60 & $448.79^{c}$ & $529.63^{a}$ & $486.41^{\mathrm{b}}$ & $470.71^{\mathrm{b}}$ \\
\hline & 120 & $424.12^{\mathrm{c}}$ & $485.52^{\mathrm{b}}$ & $637.32^{\mathrm{a}}$ & $561.35^{\mathrm{b}}$ \\
\hline & $120+4$ & $687.21^{\mathrm{b}}$ & $786.06^{\mathrm{a}}$ & $821.84^{a}$ & 630.23 \\
\hline & $120+8$ & $542.69^{c}$ & $697.02^{\mathrm{b}}$ & $724.69^{\mathrm{a}}$ & 533.18 \\
\hline & $120+12$ & $471.96^{\mathrm{d}}$ & $592.06^{\mathrm{b}}$ & $684.47^{\mathrm{a}}$ & 521.66 \\
\hline
\end{tabular}

Means followed by different lowercase superscript letters within rows are significantly different $(\mathrm{P}<0.05)$.

Vitamin C and SOD activities are important nutrients of kiwifruit. There was no significant difference $(\mathrm{P}>0.05)$ between kiwifruit under different ozone treatments (Table 1) within 120 days of cold storage. After 4 days on the shelf out of cold storage, Vc content in kiwifruit under each treatment reached a peak value; then, at the end of shelf life (12 d), Vc content in $120 \mu \mathrm{L} / \mathrm{L}$ ozone-treated kiwifruit was significantly higher than that in any other treatment $(\mathrm{P}<0.05)$.

At 4 days of shelf life out of cold storage, SOD activity reached a peak value under each different treatment, among which, activity in kiwifruit treated with ozone at 100 or $200 \mu \mathrm{L} / \mathrm{L}$ was significantly higher than in the control treatment $(\mathrm{P}<0.05)$, whereas at $300 \mu \mathrm{L} / \mathrm{L}$, the activity was significantly lower than in controls $(\mathrm{P}<0.05)$, which indicated that high concentrations of ozone inhibited SOD activity. At the end of shelf life (12 d), SOD activity of ozone-treated kiwifruit at $200 \mu \mathrm{L} / \mathrm{L}$ was significantly higher than that in any other treatment $(\mathrm{P}<0.05)$. Therefore, this ozone concentration was beneficial to prevent Vc and SOD activity from decreasing, whereby fruits retained their nutritional quality.

\section{Effect of $\mathrm{O}_{3}$ treatment on $\mathrm{POD}$ and $\mathrm{PG}$ activities}

The storage effects on fruits are closely related to changes in POD and PG activities. As POD catalyzes the decomposition of hydrogen peroxide, which is the product of SOD action, into harmless oxygen and water, POD activity can be regarded as an important indicator of the ability of the system to remove free radicals. As Figure 4A shows, POD activity of post-harvest blueberries shows an upward trend. The rapid burst in POD activity in the early storage period may be caused by low temperature stress, while the rapid increase in the POD activity in the late storage period may be caused by fruit senescence in addition to the harsh environment. Here, we found no significant difference in POD activity among the various treatments during storage $(\mathrm{P}>0.05)$. At the end of shelf life, POD activity in ozone-treated fruits at $200 \mu \mathrm{L} / \mathrm{L}$ was significantly higher than in any other treatment $(\mathrm{P}<0.05)$.

Polygalacturonase (PG) can disintegrate the cell wall by breaking the 1,4-2-D- galactosidic bonds in pectin molecules, thus affecting the degree of softening of fruit flesh; furthermore, PG activity is positively correlated with soluble pectin content. As Figure 4B shows, there was no significant difference in fruit PG activity under different ozone treatments within 60 days of cold storage $(\mathrm{P}>0.05)$. However, starting at 120 days of cold storage and until the end of shelf life, $\mathrm{PG}$ was significantly higher in the control treatment than in any ozone treatment $(\mathrm{P}<0.05)$, although there was no significant difference in the effect of different ozone concentrations on PG activity in kiwifruit flesh $(\mathrm{P}>0.05)$, which indicated that PG activity was significantly affected by ozone and that ozone inhibited the increase of PG activity in kiwifruit and maintained greater firmness of kiwifruit (Figure 1), a finding that was consistent with results of Minas et al. (2012). 

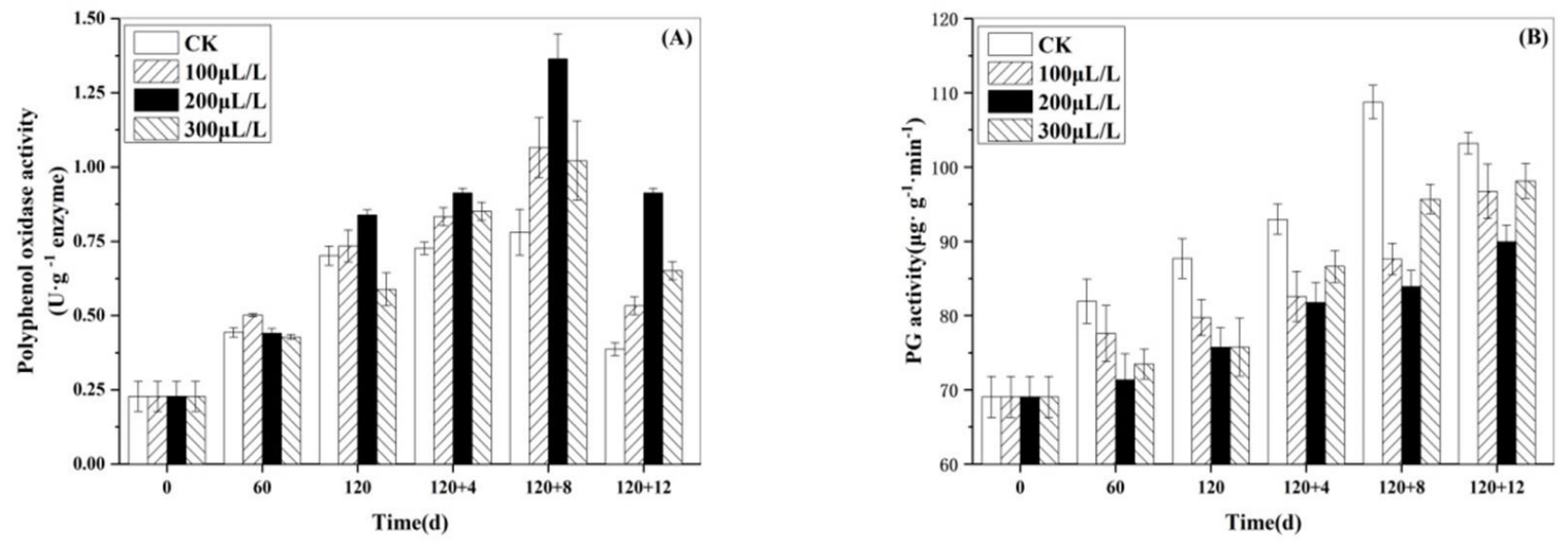

Figure 4. Effect of ozone $(0,100,200$, and $300 \mu \mathrm{L} / \mathrm{L})$ treatment on POD (A) and PG (B) activities in kiwifruit during postharvest storage at $1 \pm$ $0.5^{\circ} \mathrm{C}$ and $85 \% \pm 5 \% \mathrm{RH}$.

Ozone blocks ethylene biosynthesis by preventing ACC synthesis through the inhibition of ACS expression and activity

In plant cells, ethylene is synthesized by conversion of s-adenosylmethionine (SAM) into 1-aminocyclopropyl1-carboxylic acid (ACC) by ACC synthase (ACS). ACC is subsequently oxidized by ACC oxidase (referred to as ACO in this study) to produce ethylene and carbon dioxide $\left(\mathrm{CO}_{2}\right)$, as well as cyanide (Yang \& Hoffman, 2003). Consequently, the production rate of ethylene is controlled by the level of ACC, its direct precursor (Bouzayen et al., 1988). Generally, ethylene production in plants is maintained at a low base level, but it will be induced rather suddenly at some stages of development or under stress conditions. Although ACS is usually considered as the rate-limiting step in ethylene biosynthesis, there is evidence that ACO is used as a control point under specific developmental and stress conditions in different plant species (Qin et al., 2007).

On the contrary, although MACC is not considered as an important storage form of ACC, ACC malonylation can ALSO regulate ACC level (Hoffman et al., 1983). Therefore, to describe the effects of different concentrations of ozone treatment on ethylene biosynthesis, we decided to study the changes in ACC and MACC content. During the period of cold storage, ACC and MACC content in kiwifruit were very low (Figure 5A and Figure 5B). At the beginning of shelf life, ACC and MACC content increased rapidly in kiwifruit. After 12 days of shelf life, fruit ACC content in the control treatment was significantly higher than in ozone-treated fruit $(\mathrm{P}<0.05)$; further, ozone treatment at $200 \mu \mathrm{L} / \mathrm{L}$ had the highest inhibitory effect on ACC and MACC accumulation, whereas treatment with ozone at $300 \mu \mathrm{L} / \mathrm{L}$ was not better than the $200 \mu \mathrm{L} / \mathrm{L}$ treatment, which indicated that the accumulation of ACC and MACC could be greatly inhibited by treating fruits with the appropriate ozone concentration.

ACC synthase (ACS) and ACC oxidase (ACO) are encoded by a multi-gene family in most plant organs (Zarembinski \& Theologis, 1994). Further, ethylene biosynthesis has been shown to be regulated by positive and negative feedback mechanisms (Kende, 1993). In an attempt to further elucidate the mechanism underlying ozone inhibition of ethylene production during kiwifruit maturation we evaluated ACS and ACO activities.
As shown in Figure 5C, ACS activity initially increased but then decreased concomitantly to fruit softening; further, ozone treatment inhibited ACS activity. Within 60 days of cold storage, ACS activity remained at a very low level, indicating that high concentration ozone treatment significantly inhibited ACS activity $(\mathrm{P}<0.05)$. Starting on day 4 out of cold storage, and until the end of shelf life (12 d), the extent of inhibition of ACS activity by ozone treatment at a high concentration $(300 \mu \mathrm{L} / \mathrm{L})$ was not as large as the extent of inhibition attained at a low concentration $(100 \mu \mathrm{L} / \mathrm{L})$. Ozone treatment inhibited the increase in ACO activity, which began to decrease after 8 days on the shelf, out of cold storage (Figure 5D), which may be due to the fast decay rate of kiwifruit at the end of shelf life (Figure 1); this finding was consistent with results of Ma et al. (2009).

According to Ilina et al. (2010), AdACS1 and AdACO1, are ethylene-olefin biosynthesis genes encoding ACC synthase and ACC oxidase, respectively. Therefore, herein, we isolated and cloned these genes and monitored their expression in kiwifruit during cold storage and shelf life (Figure 5E and Figure 5F). Gene expression analysis showed that ozone inhibited expression of AdACS1 in kiwifruit. Since the day 8 on the shelf out of cold storage, kiwifruit under different treatments showed downregulation of AdACS1 expression (Figure 5E). Similarly, AdACO1 under different treatments showed an upward trend during cold storage but subsequently, from day 8 on the shelf out of cold storage, kiwifruit in the different treatments showed a downregulation trend for AdACO1 expression (Figure 5F), whereas in the control treatment both genes were much more highly expressed than under ozone treatment. These results indicated that the inhibition of ethylene biosynthesis by ozone in kiwifruit may be due to a mechanism involving residual inhibition of ethylene biosynthesis. This kind of "start-up" effect of ozone has been reported in the study of Arabidopsis, which provided evidence for the theory that ozone pre-treatment can effectively elicit the plant stress response to environmental stress (Evans et al., 2005). Moreover, this kind of ozone action can be mediated by various signal intermediates generated under ozonederived oxidation conditions, especially the stress generated during long-term cold storage of kiwifruit. Therefore, it can be inferred that the physiological and biochemical reactions after 

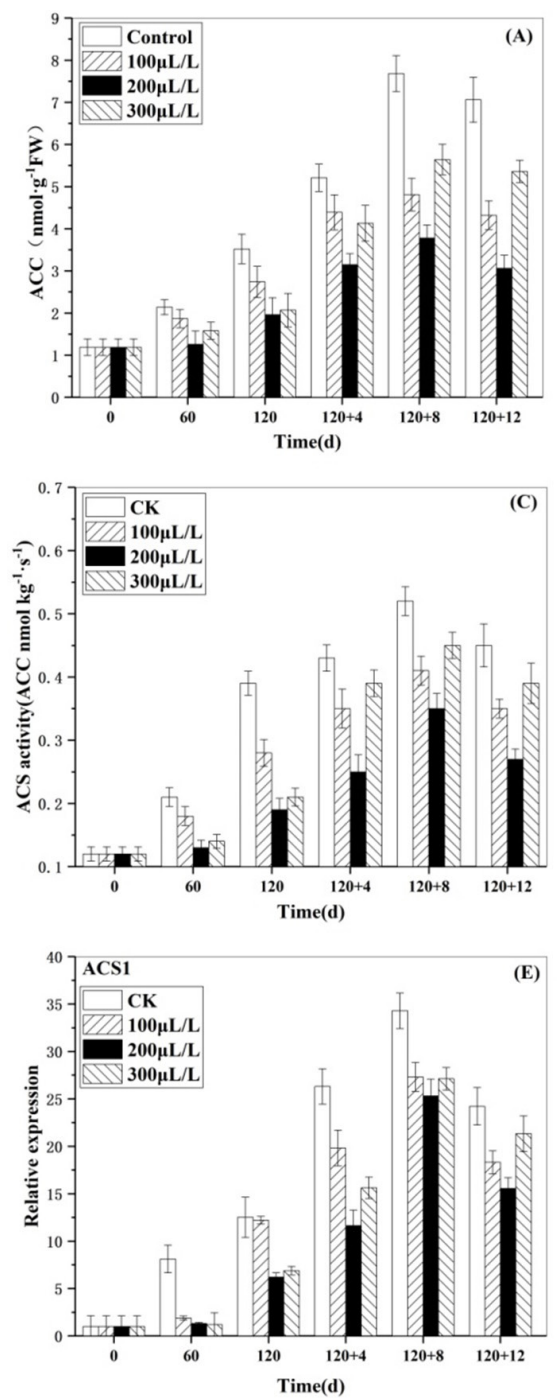
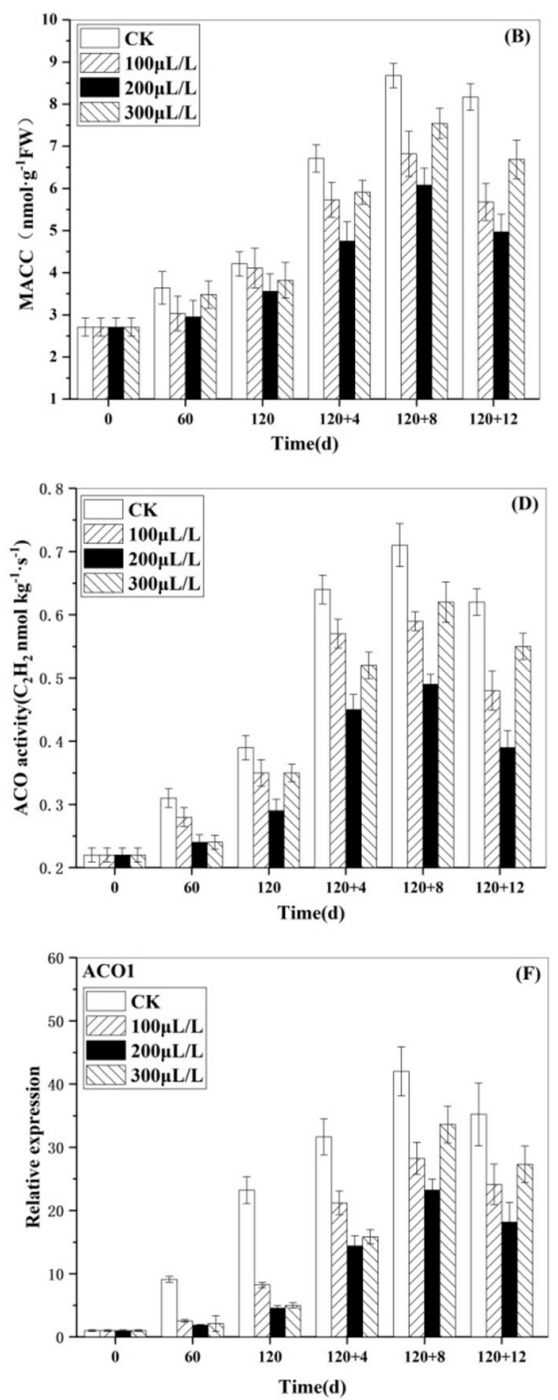

Figure 5. Effect of ozone $(0,100,200$, and $300 \mu \mathrm{L} / \mathrm{L})$ treatment on ethylene biosynthesis, including ACC (A), MACC (B), ACS (C), ACO (D), ACS1 (E) and ACO1 (F), in kiwifruit during postharvest storage at $1 \pm 0.5^{\circ} \mathrm{C}$ and $85 \% \pm 5 \% \mathrm{RH}$.

ozone treatment in Arabidopsis are closely related to the stress reactions of ethylene, salicylic acid (SA), abscisic acid (ABA) and nitric oxide (NO). As a result, in addition to regulating the biosynthesis of ethylene, ozone can also adjust the content and balance of various plant hormones during fruit ripening, thus participating in the mechanism of regulation of fruit ripening. According to Minas et al. (2014), from a commercial point of view, when the fruits treated with ozone are edible, their taste is close to that of kiwifruit ripening at $20^{\circ} \mathrm{C}$. However, our study showed that the appropriate ozone concentration can effectively inhibit ethylene biosynthesis in fruit, thereby delaying decay of the physiological quality of the fruit. As for the physiological and biochemical mechanisms whereby ozone regulates fruit ripening, it is an issue that requires further in-depth research.

\subsection{Evaluation of Botrytis during storage}

During the 120-day period under refrigeration, gray mold in the control treatment increased continuously, whereas the mold was significantly reduced in ozone-treated fruit (Figure 6),

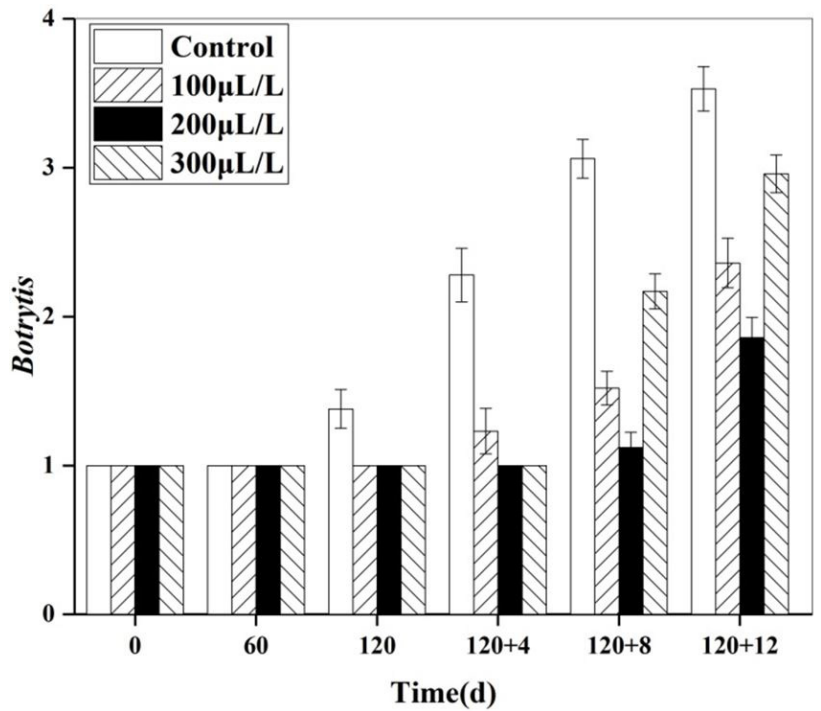

Figure 6. Effect of ozone $(0,100,200,300 \mu \mathrm{L} / \mathrm{L})$ treatment on Botrytis incidence in kiwifruit during postharvest storage at $1 \pm 0.5^{\circ} \mathrm{C}$ and $85 \% \pm 5 \% \mathrm{RH}$. 


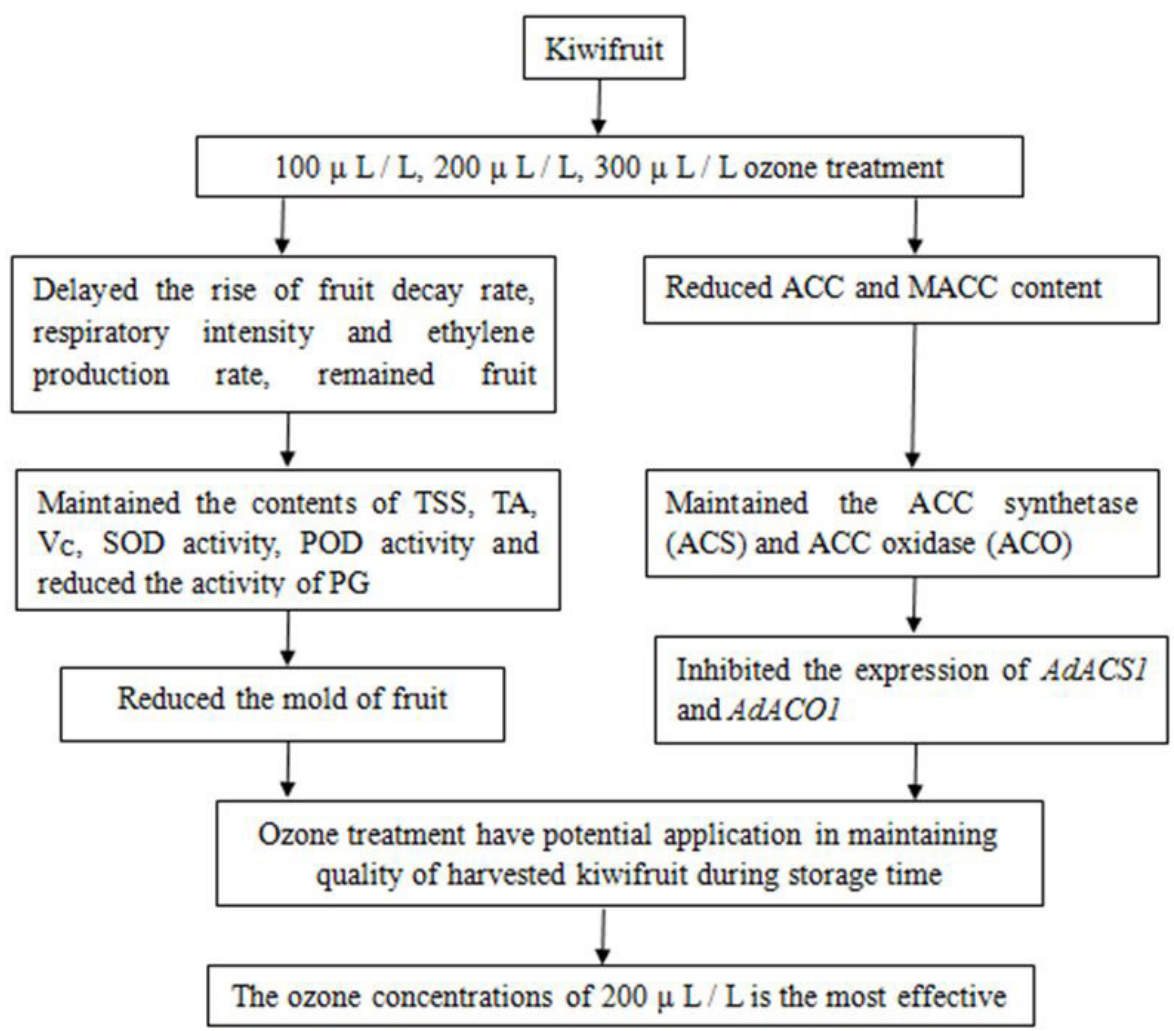

Figure 7. The probable mechanism of ozone treatment treatments-improved fruit quality of harvested kiwifruit through reduced mold and sinhibited the expression of AdACS1 and AdACO1.

which was consistent with results by Barboni et al. (2010). During the period of shelf life, gray mold began to increase in kiwifruit treated with different concentrations of ozone. At the later stages of shelf life, gray mold increased rapidly in kiwifruit treated with ozone at $300 \mu \mathrm{L} / \mathrm{L}$, likely due to accelerated fruit senescence cause by this high concentration of ozone (Figure 1), thus resulting in a decrease in the ability of the fruit to resist microbial infection. There are several reports on the effect of ozone treatment on microorganisms in fruits and vegetables (Karaca \& Velioglu, 2007). Gray mold caused by Botrytis in fruits at post-harvest is an important factor causing fruit rot (Michailides \& Elmer, 2000), therefore, it is a determinant of potential fruit losses during storage. Undoubtedly, treatment of kiwifruit with an appropriate concentration of ozone will have highly beneficial effects on fruit quality preservation during storage (Figure 7).

\section{Conclusions}

The results reported herein showed that ozone treatment promoted better storage fruit quality and significantly reduced fruit rotting and delayed kiwifruit ripening and senescence. The most appropriate ozone concentration to achieve these effects was $200 \mu \mathrm{L} / \mathrm{L}$. At this concentration, ozone effectively inhibited an early increase in fruit rotting rate, respiratory rate and ethylene production rate, thereby contributing substantially to a significant delay in the decline of fruit firmness and nutritional quality, to maintain fruit enzyme activity, and to effectively inhibit ethylene biosynthesis in fruits, as well as to preserve the physiological quality of fruits. Overall, considering kiwifruit as a model crop, this study provides a novel strategy to use ozone for fruit preservation. Moreover, our data provided novel insights into the mechanisms underlying fruit ripening that will surely make an important contribution to expanding our knowledge of fruit ripening.

\section{Acknowledgements}

This work was financially supported by Scientific research platform For Qian Ke He [2019]5644, and Guiyang science and technology plan project (Zhuke contract [2020] No. 37-2). This work was financially supported by the scientific research funds of Guiyang University [GYU-KY-(2021)].

\section{References}

Antunes, M. D. C., \& Sfakiotakis, E. M. (2002). Ethylene biosynthesis and ripening behaviour of 'Hayward' kiwifruit subjected to some controlled atmospheres. Postharvest Biology and Technology, 26(2), 167-179. http://dx.doi.org/10.1016/S0925-5214(02)00040-6.

Barboni, T., Cannac, M., \& Chiaramonti, N. (2010). Effect of cold storage and ozone treatment on physicochemical parameters, soluble sugars and organic acids in Actinidia deliciosa. Food Chemistry, 121(4), 946-951. http://dx.doi.org/10.1016/j.foodchem.2010.01.024.

Bardas, G. A., Veloukas, T., Koutita, O., \& Karaoglanidis, G. S. (2010). Multiple resistance of Botrytis cinerea from kiwifruit to SDHIs, QoIs and fungicides of other chemical groups. Pest Management Science, 66(9), 967-973. http://dx.doi.org/10.1002/ps.1968. PMid:20730988. 
Bastos, R. G., Oliver, J. C., Germano, J. L., Fernandes, G. R., \& Veiga, S. M. D. M. (2019). Effectiveness evaluation of alternative sanitizers in microbiological quality of strawberry (Fragaria ananassa Duch Var. Oso Grande) after artificial contamination by Escherichia coli. Food Science and Technology, 39(Suppl. 2), 470-474. http://dx.doi. org/10.1590/fst.21118.

Bernardi, R., Jorge, L. M. D. M., \& Paraíso, P. R. (2019). Kinetic modeling of sugarcane juice clarification by ozonation in batch reactor with ozone saturation control. Food Science and Technology, 39(Suppl. 1), 81-84. http://dx.doi.org/10.1590/fst.35417.

Bouzayen, M., Latche, A., Alibert, G., \& Pech, J. C. (1988). Intracellular sites of synthesis and storage of 1-(Malonylamino)cyclopropane-1Carboxylic acid in Acer pseudoplatanus cells. Plant Physiology, 88(3), 613-617. http://dx.doi.org/10.1104/pp.88.3.613. PMid:16666357.

Bulens, I., Van de Poel, B., Hertog, M. L., De Proft, M. P., Geeraerd, A. H., \& Nicolaï, B. M. (2011). Protocol: an updated integrated methodology for analysis of metabolites and enzyme activities of ethylene biosynthesis. Plant Methods, 7(1), 17-17. http://dx.doi. org/10.1186/1746-4811-7-17. PMid:21696643.

Chen, Y. Z., \& Wang, Y. R. (1989). A study on peroxidase in litchi pericarp. Acta Botanica Sinica, 5, 47-52.

Costa, J. N., Brito, S. A., Leal, A. R., Rodrigues, D. C., Nascimento, L. G. L., Figueiredo, R. W., Mata, P., \& Sousa, P. H. M. (2020). Sensory characteristics of structured guava (Psidium guajava): comparison of optimized descriptive profile, cata and sensory acceptance methods. Food Science and Technology, 40(Suppl. 2), 496-502. http://dx.doi. org/10.1590/fst.25819.

Daş, E., Gürakan, G. C., \& Bayindirli, A. (2006). Effect of controlled atmosphere storage, modified atmosphere packaging and gaseous ozone treatment on the survival of Salmonella Enteritidis on cherry tomatoes. Food Microbiology, 23(5), 430-438. http://dx.doi. org/10.1016/j.fm.2005.08.002. PMid:16943034.

Di Francesco, A., Mari, M., Ugolini, L., \& Baraldi, E. (2018). Effect of Aureobasidium pullulans strains against Botrytis cinerea on kiwifruit during storage and on fruit nutritional composition. Food Microbiology, 72, 67-72. http://dx.doi.org/10.1016/j.fm.2017.11.010. PMid:29407406.

Elmer, P. A. G., \& Michailides, T. J. (2007). Epidemiology of Botrytis cinerea in orchard and vine crops. In Y. Elad, B. Williamson, P. Tudzynski \& N. Delen (Eds.), Botrytis: biology, pathology and control (pp. 243-272). Netherlands: Springer. http://dx.doi.org/10.1007/9781-4020-2626-3_14.

Evans, N. H., McAinsh, M. R., Hetherington, A. M., \& Knight, M. R. (2005). ROS perception in Arabidopsis thaliana: the ozone-induced calcium response. The Plant Journal, 41(4), 615-626. http://dx.doi. org/10.1111/j.1365-313X.2004.02325.x. PMid:15686524.

Gabler, F. M., Smilanick, J. L., Mansour, M. F., \& Karaca, H. (2010). Influence of fumigation with high concentrations of ozone gas on postharvest gray mold and fungicide residues on table grapes. Postharvest Biology and Technology, 55(2), 85-90. http://dx.doi. org/10.1016/j.postharvbio.2009.09.004.

Han, Q., Gao, H., Chen, H., Fang, X., \& Wu, W. (2017). Precooling and ozone treatments affects postharvest quality of black mulberry (Morus nigra) fruits. Food Chemistry, 221, 1947-1953. http://dx.doi. org/10.1016/j.foodchem.2016.11.152. PMid:27979184.

Hoffman, N. E., Fu, J. R., \& Yang, S. F. (1983). Identification and metabolism of 1-(Malonylamino)Cyclopropane-1-Carboxylic acid in germinating peanut seeds. Plant Physiology, 71(1), 197-199. http:// dx.doi.org/10.1104/pp.71.1.197. PMid:16662787.

Ilina, N., Alem, H. J., Pagano, E. A., \& Sozzi, G. O. (2010). Suppression of ethylene perception after exposure to cooling conditions delays the progress of softening in 'Hayward' kiwifruit. Postharvest Biology and Technology, 55(3), 160-168. http://dx.doi.org/10.1016/j. postharvbio.2009.11.005.

İpek, A., Yılmaz, K., Sıkıcı, P., Tangu, N. A., Öz, A. T., Bayraktar, M., İpek, M., \& Gülen, H. (2016). SNP discovery by GBS in olive and the construction of a high-density genetic linkage map. Biochemical Genetics, 54(3), 313-325. http://dx.doi.org/10.1007/s10528-0169721-5. PMid:26902470.

Karaca, H., \& Velioglu, Y. S. (2007). Ozone applications in fruit and vegetable processing. Food Reviews International, 23(1), 91-106. http://dx.doi.org/10.1080/87559120600998221.

Kende, H. (1993). Ethylene biosynthesis. Annual Review of Plant Physiology and Plant Molecular Biology, 44(1), 283-307. http:// dx.doi.org/10.1146/annurev.pp.44.060193.001435.

Leccese, A., Bartolini, S., \& Viti, R. (2012). Genotype, harvest season, and cold storage influence on fruit quality and antioxidant properties of apricot. International Journal of Food Properties, 15(4), 864-879. http://dx.doi.org/10.1080/10942912.2010.506019.

Ma, G., Wang, R., Wang, C. R., Kato, M., Yamawaki, K., Qin, F., \& $\mathrm{Xu}, \mathrm{H}$.-L. (2009). Effect of 1-methylcyclopropene on expression of genes for ethylene biosynthesis enzymes and ethylene receptors in post-harvest broccoli. Plant Growth Regulation, 57(3), 223-232. http://dx.doi.org/10.1007/s10725-008-9339-7.

Mahapatra, A. K., Muthukumarappan, K., \& Julson, J. L. (2005). Applications of ozone, bacteriocins and irradiation in food processing: a review. Critical Reviews in Food Science and Nutrition, 45(6), 447461. http://dx.doi.org/10.1080/10408390591034454. PMid:16183567.

Martínez-Romero, D., Bailén, G., Serrano, M., Guillén, F., Valverde, J. M., Zapata, P., Castillo, S., \& Valero, D. (2007). Tools to maintain postharvest fruit and vegetable quality through the inhibition of ethylene action: a review. Critical Reviews in Food Science and Nutrition, 47(6), 543-560. http://dx.doi.org/10.1080/10408390600846390. PMid:17653980.

Melgarejo, P., Salazar, D. M. F., \& Artés, F. (2000). Organic acids and sugars composition of harvested pomegranate fruits. European Food Research and Technology, 211(3), 185-190. http://dx.doi.org/10.1007/ s002170050021.

Michailides, T. J., \& Elmer, P. A. G. (2000). Botrytis gray mold of kiwifruit caused by Botrytis cinerea in the United States and New Zealand. Plant Disease, 84(3), 208-223. http://dx.doi.org/10.1094/ PDIS.2000.84.3.208. PMid:30841231.

Minas, I. S., Karaoglanidis, G. S., Manganaris, G. A., \& Vasilakakis, M. (2010). Effect of ozone application during cold storage of kiwifruit on the development of stem-end rot caused by Botrytis cinerea. Postharvest Biology and Technology, 58(3), 203-210. http://dx.doi. org/10.1016/j.postharvbio.2010.07.002.

Minas, I. S., Tanou, G., Belghazi, M., Job, D., Manganaris, G. A., Molassiotis, A., \& Vasilakakis, M. (2012). Physiological and proteomic approaches to address the active role of ozone in kiwifruit postharvest ripening. Journal of Experimental Botany, 63(7), 2449-2464. http://dx.doi.org/10.1093/jxb/err418. PMid:22268155.

Minas, I. S., Vicente, A. R., Dhanapal, A. P., Manganaris, G. A., Goulas, V., Vasilakakis, M., Crisosto, C. H., \& Molassiotis, A. (2014). Ozone-induced kiwifruit ripening delay is mediated by ethylene biosynthesis inhibition and cell wall dismantling regulation. Plant Science, 229, 76-85. http://dx.doi.org/10.1016/j.plantsci.2014.08.016. PMid:25443835.

Mlček, J., Valšíková, M., Družbíková, H., Ryant, P., Juríková, T., Sochor, J., \& Borkovcová, M. (2015). The antioxidant capacity and macroelement content of several onion cultivars. Turkish Journal of Agriculture and Forestry, 39, 999-1004. http://dx.doi.org/10.3906/tar-1501-71. 
Nascimento, R. Q., Tavares, P. P. L. G., Meireles, S., Anjos, E. A., Andrade, R. B., MacHado, B. A. S., Souza, A. L. C., \& Mamede, M. E. O. (2020). Study on the sensory acceptance and check all that apply of mixed juices in distinct Brazilian regions. Food Science and Technology, 40(Suppl. 2), 708-717. http://dx.doi.org/10.1590/fst.37619.

Navarro, J. M., Flores, P., Garrido, C., \& Martinez, V. (2006). Changes in the contents of antioxidant compounds in pepper fruits at different ripening stages, as affected by salinity. Food Chemistry, 96(1), 66-73. http://dx.doi.org/10.1016/j.foodchem.2005.01.057.

Niklis, N., Sfakiotakis, E., \& Thanassoulopoulos, C. C. (1997). Ethylene production by Botrytis cinerea, kiwifruit and Botrytis rotted kiwifruit under several storage temperatures. Acta Horticulturae, (444), 733738. http://dx.doi.org/10.17660/ActaHortic.1997.444.112.

Ong, M. K., Kazi, F. K., Forney, C. F., \& Ali, A. (2013). Effect of gaseous ozone on papaya anthracnose. Food and Bioprocess Technology, 6(11), 2996-3005. http://dx.doi.org/10.1007/s11947-012-1013-4.

Palou, L., Crisosto, C. H., Smilanick, J. L., Adaskaveg, J. E., \& Zoffoli, J. P. (2002). Effects of continuous 0.3 ppm ozone exposure on decay development \& physiological responses of peaches \& table grapes in cold storage. Postharvest Biology and Technology, 24(1), 39-48. http://dx.doi.org/10.1016/S0925-5214(01)00118-1.

Qin, Y.-M., Hu, C.-Y., Pang, Y., Kastaniotis, A. J., Hiltunen, J. K., \& Zhu, Y.-X. (2007). Saturated very-long-chain fatty acids promote cotton fiber and arabidopsis cell elongation. The Plant Cell, 19(11), 36923704. http://dx.doi.org/10.1105/tpc.107.054437. PMid:17993622.

Schuch, A. F., Silva, A. C. D., Kalschne, D. L., Silva-Buzanello, R. A., Corso, M. P., \& Canan, C. (2018). Chicken nuggets packaging attributes impact on consumer purchase intention. Food Sci. Technol, 39(Suppl. 1), 152-158. http://dx.doi.org/10.1590/fst.41317.

Selma, M. V., Ibáñez, A. M., Allende, A., Cantwell, M., \& Suslow, T. (2008). Effect of gaseous ozone and hot water on microbial and sensory quality of cantaloupe and potential transference of Escherichia coli O157:H7 during cutting. Food Microbiology, 25(1), 162-168. http:// dx.doi.org/10.1016/j.fm.2007.06.003. PMid:17993390.
Shimizu, Y., Makinott, S., Sato, J., \& Iwamoto, S. (1982). Preventing rot of 'Kyoho' grapes in cold storage with ozone. Res. Bull. Aichi-ken Agric. Res. Center, 14, 225-238.

Silva, L. S., Resende, O., Bessa, J. F. V., Bezerra, I. M. C., \& Tfouni, S. A. V. (2018). Ozone in polycyclic aromatic hydrocarbon degradation. Food Science and Technology, 38(Suppl. 1), 184-189. http://dx.doi. org/10.1590/fst.06817.

Soufleros, E. H., Pissa, I., Petridis, D., Lygerakis, M., Mermelas, K., Boukouvalas, G., \& Tsimitakis, E. (2001). Instrumental analysis of volatile and other compounds of Greek kiwi wine; sensory evaluation and optimisation of its composition. Food Chemistry, 75(4), 487-500. http://dx.doi.org/10.1016/S0308-8146(01)00207-2.

Stec, M. G. H., Hodgson, J. A., Macrae, E. A., \& Triggs, C. M. (1989). Role of fruit firmness in the sensory evaluation of kiwifruit (Actinidia deliciosa, cv Hayward). Journal of the Science of Food and Agriculture, 47(4), 417-433. http://dx.doi.org/10.1002/jsfa.2740470404.

Tzortzakis, N., Borland, A., Singleton, I., \& Barnes, J. (2007). Impact of atmospheric ozone-enrichment on quality-related attributes of tomato fruit. Postharvest Biology and Technology, 45(3), 317-325. http://dx.doi.org/10.1016/j.postharvbio.2007.03.004.

Whangchai, K., Saengnil, K., \& Uthaibutra, J. (2006). Effect of ozone in combination with some organic acids on the control of postharvest decay and pericarp browning of longan fruit. Crop Protection, 25(8), 821-825. http://dx.doi.org/10.1016/j.cropro.2005.11.003.

Yang, S. F., \& Hoffman, N. E. (2003). Ethylene biosynthesis and its regulation in higher plants. Annual Review of Plant Physiology, 35(1), 155-189. http://dx.doi.org/10.1146/annurev.pp.35.060184.001103.

Yin, X. R., Allan, A. C., Chen, K. S., \& Ferguson, I. B. (2010). Kiwifruit EIL and ERF genes involved in regulating fruit ripening. Plant Physiology, 153(3), 1280-1292. http://dx.doi.org/10.1104/pp.110.157081. PMid:20457803.

Zarembinski, T. I., \& Theologis, A. (1994). Ethylene biosynthesis and action: a case of conservation. Plant Molecular Biology, 26(5), 1579-1597. http://dx.doi.org/10.1007/BF00016491. PMid:7858205. 
Original Article

\section{Ozone effects on v storage and preservation}

\section{Supplementary Material}

Supplementary material accompanies this paper.

Supplementary Table 1. Primer sequences

This material is available as part of the online article from http://www.scielo.br/cta 